\title{
1 Hit or miss: Glacial incisions of snowball Earth
}

3 Ross N. Mitchell ${ }^{1}$, Thomas M. Gernon ${ }^{2}$, Adam Nordsvan ${ }^{1}$, Grant M. Cox ${ }^{3}$, Zheng-Xiang Li ${ }^{1}$, and

4 Paul F. Hoffman ${ }^{4,5}$

6 Estimated at 258 Myr in duration, the Sturtian snowball Earth (ca. 717-659 Ma) is one of the longest-known glaciations in Earth history. Surprisingly few uncontroversial lines of evidence for glacial incisions associated with such a protracted event exist. We report here multiple lines of geologic field evidence for deep but variable glacial erosion during the Sturtian glaciation. One incision, on the scale of several kilometers, represents the deepest incision documented for snowball Earth; another much more modest glacial valley, however, suggests an erosion rate similar to sluggish Quaternary glaciers. The heterogeneity in snowball glacial incisions reported here and elsewhere were likely influenced by actively extending horst-and-graben topography associated with the breakup of supercontinent Rodinia.

Introduction

17 [1] Unlike Phanerozoic ice sheets that are exclusively restricted to high-to-mid-latitude glaciations 18 (Evans, 2003), several Precambrian glaciations show an affinity for "snowball Earth" conditions (Evans, 2000; Evans et al., 1997; Hoffman et al., 1998; Kirschvink, 1992), whereby an ice albedo bifurcation allowed polar ice caps to expand into the tropics and meet at the equator (Budyko, 1969; Sellers, 1969).

21 Two globally correlative snowball events occurred in the Neoproterozoic Era, the ca. 717-659 Ma

${ }^{1}$ Earth Dynamics Research Group, The Institute for Geoscience Research (TIGeR), Department of Applied Geology, Curtin University, GPO Box U1987, WA 6845, Australia. ${ }^{2}$ Ocean and Earth Science, University of Southampton, Southampton SO14 3ZH, United Kingdom. ${ }^{3}$ Dept. of Earth Sciences, The University of Adelaide, Adelaide, S.A. 5005, Australia. ${ }^{4}$ Department of Earth and Planetary Sciences, Harvard University, Cambridge, MA 02138, USA. ${ }^{5}$ School of Earth and Ocean Sciences, University of Victoria, Victoria, British Columbia V8P 5C2, Canada. 
22 "Sturtian" and ca. 650-635 Ma "Marinoan", defining Cryogenian time (Bao et al., 2018; Macdonald et

23 al., 2010; Rooney et al., 2015; Shields-Zhou et al., 2016). The glacial-periglacial origin of Cryogenian

24 diamictites is widely accepted and the snowball Earth hypothesis has gained favor since globally

25 synchronous glacial terminations are increasingly supported radiometrically (Cox et al., 2018; Rooney et

26 al., 2015). The longer of the two Cryogenian glaciations, the $~ 58-\mathrm{Myr}-$-long Sturtian glaciation (Cox et

27 al., 2018; Rooney et al., 2015), thus represents one of the longest-known glaciations in Earth history.

29 [2] There is little consensus over how much glacial erosion occurred during the Cryogenian snowball

30 Earth events. Recently, a provocative hypothesis links Cryogenian snowball events the origin of the

31 Great Unconformity (Keller et al., 2019). Citing anomalies in zircon geochemistry as well as the absence

32 of shallow impact craters older than Cryogenian age, the lines of evidence presented for Neoproterozoic

33 glacial erosion by Keller et al. (2019) are arguably independent of whether their inferred link with the

34 Cambrian Great Unconformity is indeed proven viable. If the geochemical inferences of Keller et al.

35 (2019) are correct, and their estimate of $\sim 4 \mathrm{~km}$ of globally-integrated Neoproterozoic glacial erosion is

36 accurate, then presumably abundant geologic field evidence for such glacial erosion should exist. To

37 date, surprisingly few documented examples of Cryogenian incisions have been documented (Hoffman

38 et al., 2017). It should be noted that the presence of localized glacial incisions does not equate to basin-

39 or continent-scale erosion, and understanding how such localized incisions integrate globally and relate

40 to broader (typically slower) erosion rates is complex. Because of the kilometer-scale fall in global mean

41 sea level associated with snowball Earth (Liu and Peltier, 2013), both localized incision and regional

42 erosion both likely took place and are not mutually exclusive, even though they are distinct. 
44 [3] In this paper we report two lines of internally consistent geologic field evidence from the Flinders

45 Ranges of South Australia for significant but variable glacial erosion associated with the Sturtian

46 glaciation. Localized large-scale erosion on the order of several kilometers is shown to have occurred in

47 a glacial trough, possibly enhanced by tectonic uplift. Elsewhere, however, considerably less erosion

48 occurred $(<<1 \mathrm{~km})$. Heterogeneity of glacial erosion on the relatively small scale of the Northern

49 Flinders Ranges documented here is further supported by variable depths of Cryogenian incisions

50 compiled from around the world, suggesting an underlying influence of the breakup of supercontinent

51 Rodinia on glacial erosion.

52

\section{Geologic setting}

54 [4] The Adelaidean Inlier of south Australia is a thick late Neoproterozoic sedimentary succession (Fig.

55 1), correlative with similar deposits in the Centralian Superbasin to the northwest (Preiss, 1987).

56 Neoproterozoic strata exposed at Arkaroola of the Northern Flinders Ranges represent the northern limit

57 of the Adelaidean Inlier, and Sturtian tillites of the Yudnamutana Subgroup have been noted for their

58 exceptional, fault-related thicknesses (Young and Gostin, 1989), presumably indirect evidence of

59 significant incision. In the sedimentary sequence of Tillite Gorge $\left(30.3^{\circ} \mathrm{S}, 139.4^{\circ} \mathrm{E}\right)$, the Sturtian

60 glaciation is represented by the Merinjina Formation (Fig. 2). Le Heron et al. (2014) refer to the Tillite

61 Gorge section as Bolla Bollana Formation, but that unit may be distinct in age from the Merinjina

62 Formation. A well-developed, 2.5-4.5-m-thick cap dolomite including apparent shallow-water bedforms

63 overlies the glacial facies in the Tillite Gorge area. Glacial facies thin basinward, away from the Stuart

64 Shelf, ranging in thickness from $\sim 780 \mathrm{~m}$ at Mount Jacob $\sim 2.5 \mathrm{~km}$ north of "Wooltana" (Mawson, 1949)

65 to $\sim 660 \mathrm{~m}$ in Tillite Gorge (Fig. 2), to $\sim 500 \mathrm{~m}$ to the south (Preiss, 1987). The most common glacial

66 facies are tillites characterized by clasts ranging in size from pebbles to boulders and ranging in 
67 composition, including dominantly quartzite, basalt, and dolomite clasts (Preiss, 1987) (Fig. 3). Sources

68 of such lithologies are unlikely to be far-traveled and are attributable to immediately older and directly

69 underlying units found both locally (the Skillogalee Dolomite, the Wortupa and Copley Quartzites, and 70 the ca. 825 Ma Wooltana Volcanics; Fig. 1) and regionally in the Centralian Superbasin (e.g., the Bitter

71 Springs Formation, the Heavitree Quartzite, etc.) (Preiss, 1987).

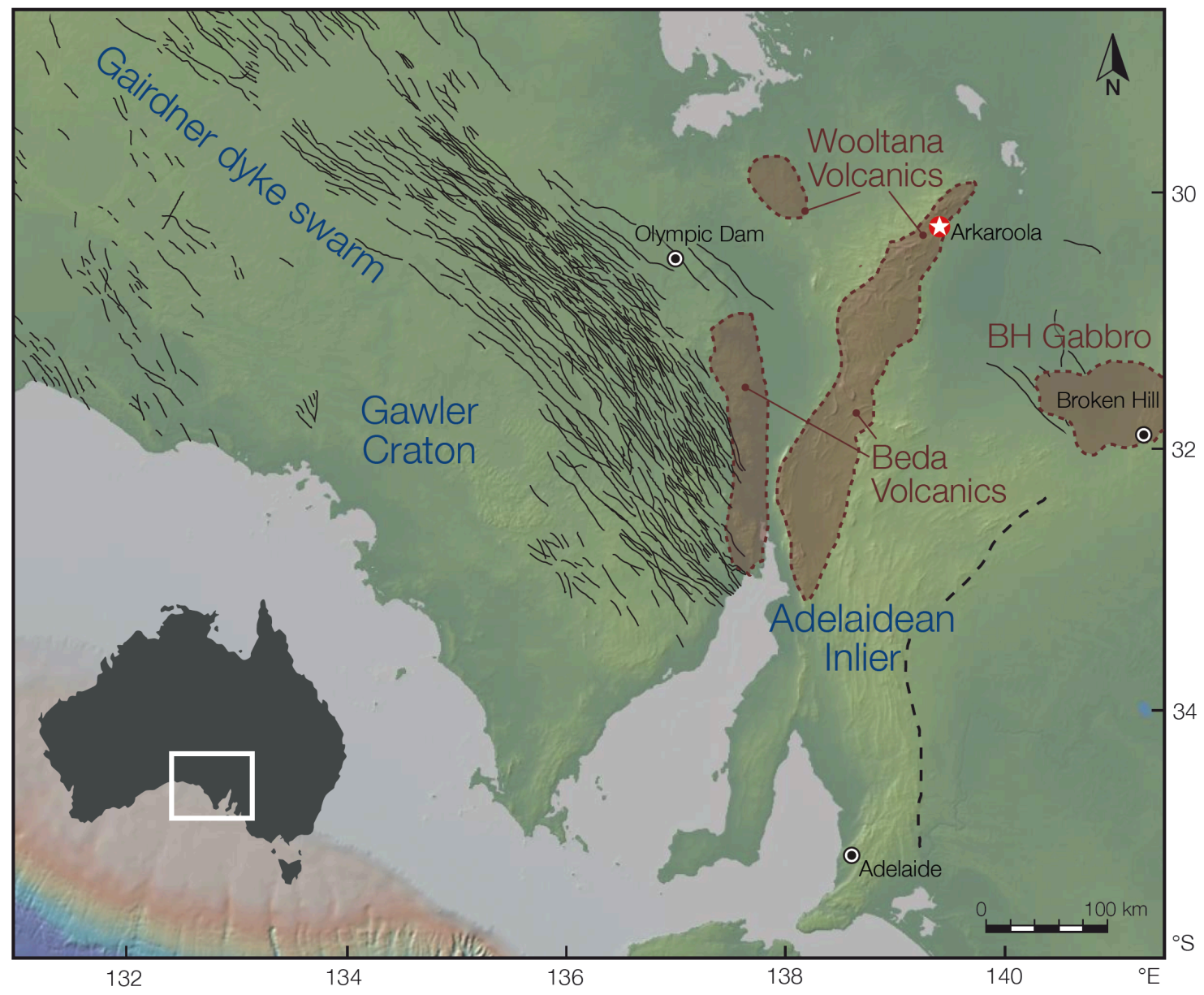

73 Fig. 1 Map of South Australia depicting the ca. 820-830 Ma Gairdner large igneous province (modified from 74 Huang et al. (2015)). Star indicates location of Tillite Gorge, Arkaroola.

75

76 [5] This study focuses on the mafic clasts in the Sturtian tillite presumably derived locally from the

77 underlying Wooltana Volcanics. The arcuate Gairdner dykes dated at $827 \pm 6 \mathrm{Ma}$ (Wingate et al., 1998)

78 are the longest swarm on the continent and represent the main expression of the ca. $820-830 \mathrm{Ma}$ 
79 Gairdner large igneous province that includes the Wooltana Volcanics, Beda Volcanics, and the Little

80 Broken Hill Gabbro (Zhao et al., 1994) (Fig. 1). Furthermore, the identification of northwest-southeast

81 trending dykes underground at both the Olympic Dam and Broken Hill mines (Huang et al., 2015),

82 suggest the width of the giant Gairdner dyke swarm is as significant as its considerable length and now

83 extends as far northeast as Arkaroola. From previous geologic mapping of the Arkaroola area alone

84 (Coats, 1973), one can glean evidence for highly variable glacial erosion during the Sturtian glaciation,

85 as deep as the Wooltana Volcanics in places (Fig. 2). Comparison of the magnetic susceptibility of

86 Wooltana clasts in the Sturtian tillite to the values of nearby stratigraphic sections of the Wooltana

87 Volcanics allows us to further deduce the maximum depth of glacial erosion.
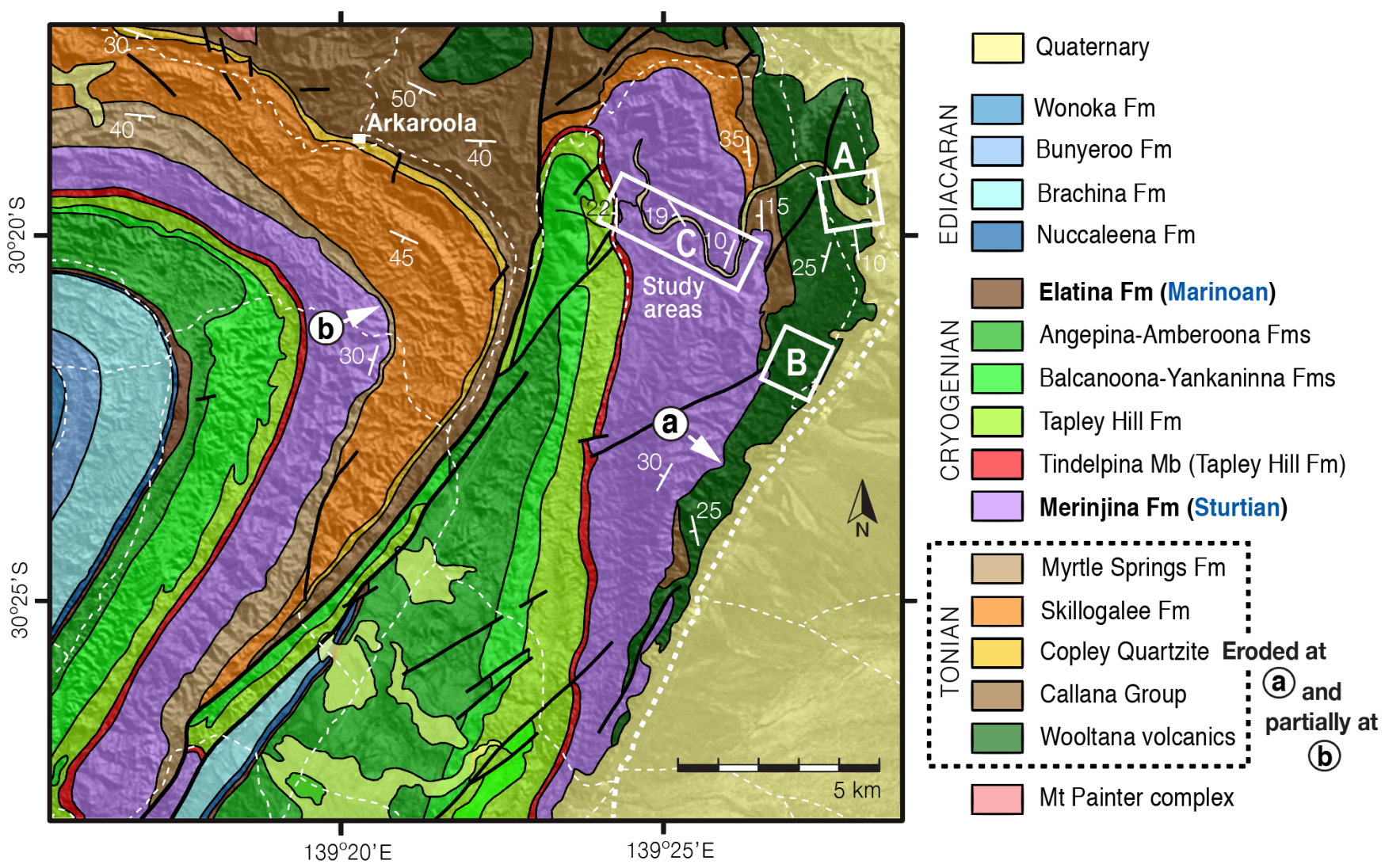

Fig. 2 Geologic map of the Arkaroola area (modified from Coats, 1973) indicating three measured stratigraphic sections: (A and B) the Wooltana Volcanics and (C) the Merinjina Formation. Sections A and B constitute a composite section of the entire exposed Wooltana Volcanics, supported by magnetic susceptibility measurements (Fig. 6A). Section $\mathrm{C}$ is Tillite Gorge (Fig. 5). Both deep and shallow glacial troughs are interpreted (a and b), respectively. Thick solid lines, faults; thin solid lines, geological boundaries; dashed lines, roads and tracks. 


\section{Geologic mapping of glacial erosion}

95 [6] Evidence for glacial troughs is observed in the detailed mapping in the Arkaroola area (Fig. 2). East

96 of Arkaroola, the specific field area of this study, the large proportion of basaltic clasts observed at all

97 levels in Tillite Gorge implies that the underlying Tonian stratigraphy was incised as deep as the

98 Wooltana Volcanics (Fig. 3). At Merinjina Well, the contact between the Merinjina Tillite and the

99 underlying Wooltana Volcanics is striated and interpreted as a glacial pavement (Mirams, 1964) (Fig. 4).

100 Although a tectonic origin for the striated surface was also suggested (Daily et al., 1973), the weight of

101 evidence indicates that the grooved pavement at Merinjina Well is glacial in origin (Preiss, 1987). The 102 base of the Merinjina Tillite lies unconformably on several underlying units, down to the level of the 103 Wooltana volcanics, implying deep, but localized glacial erosion.

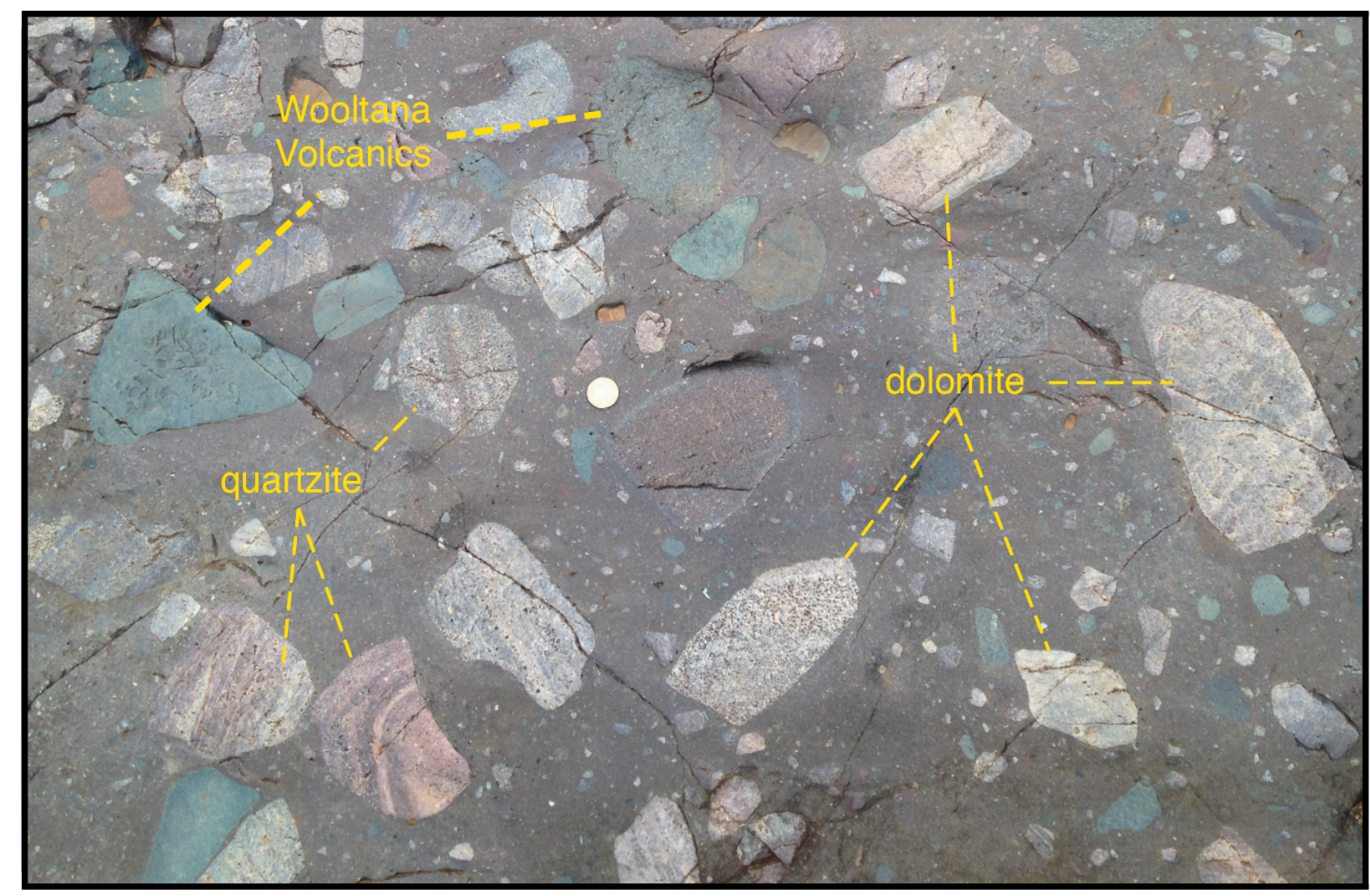

Fig. 3. Merinjina Formation at Tillite Gorge (Fig. 2). Note flat surfaces important for measuring susceptibility with hand-held meter. Examples of clasts of Wooltana Volcanics measured indicated. Other clasts (e.g., dolomite and quartzite) have multiple possible provenances mentioned in the text. 


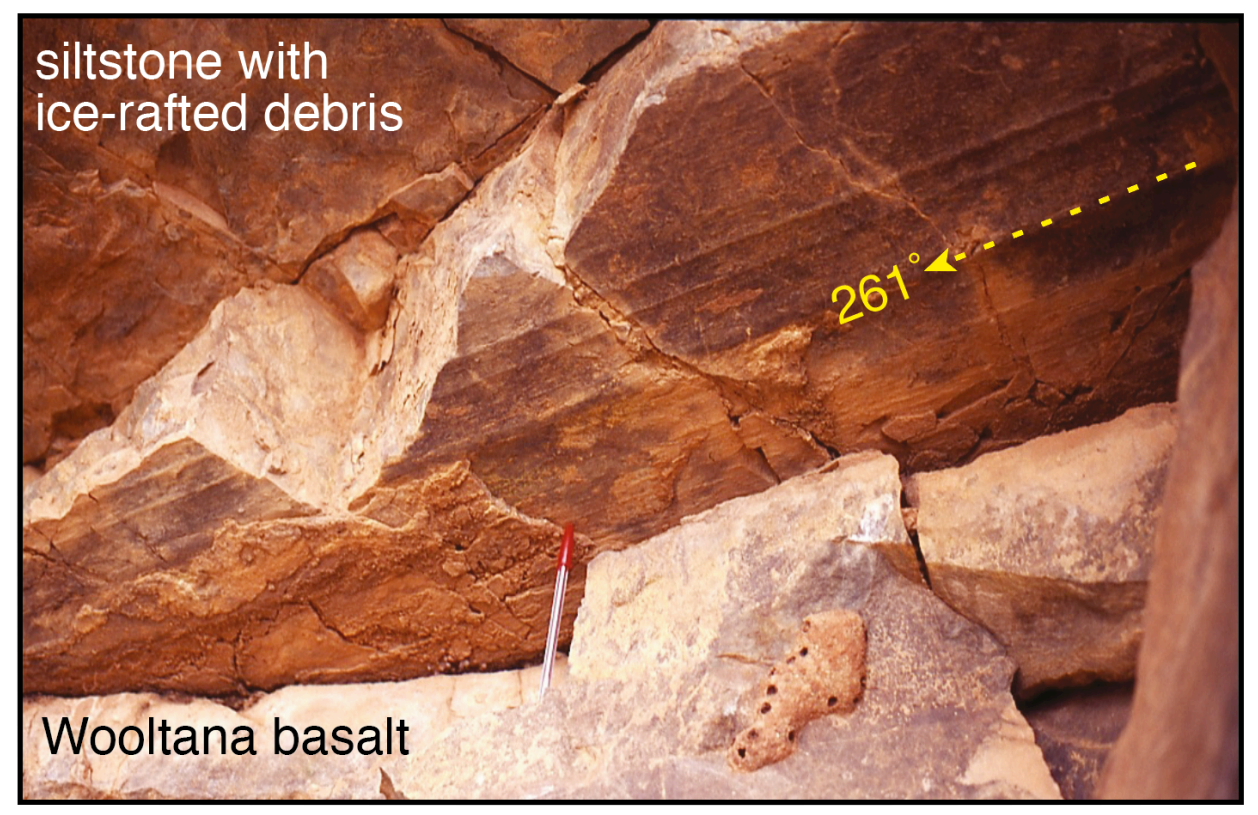

109 Fig. 4 Striated glacial pavement in Wooltana Volcanics at Merinjina Well. The grooved surface is a cast of the 110 Wooltana pavement preserved at the base of a synglacial (basal Merinjina Formation) siltstone with ice-rafted 111 debris, exposed on an overhang where the underlying basalt has fallen away.

113 [7] Using geologic relationships, we estimate the thicknesses of underlying, eroded units in the areas 114 closest to each of the two glacial incisions documented (Fig. 2). West of Arkaroola at 'b' on the map 115 (Fig. 2), where Merinjina Formation is in contact with the Myrtle Springs Formation (700-800 m thick), 116 we estimate the smaller glacial trough to be only 500-600 m deep, i.e., eroding most, but not all, of the 117 Myrtle Springs Formation. East of Arkaroola at 'a' on the map (Fig. 2), where Merinjina Formation is in 118 contact with the Wooltana Volcanics (Fig. 4), the entire Tonian sedimentary cover has been removed. 119 However, the synsedimentary Paralana Fault bisecting Arkaroola appears to have strongly affected 120 deposition, with much thicker strata west of Arkaroola and thinning to the east (e.g., Copley Quartzite 121 does not even occur east of Arkaroola; Fig. 2) (Mawson, 1949; Paul et al., 1999; Preiss, 1987). The 122 Callana Group is the only unit whose whole thickness is preserved on the east side, allowing for 123 comparison across the fault: $1.2 \mathrm{~km}$ (west) and $0.37 \mathrm{~km}$ (east), implying a $\sim 69 \%$ reduction in thickness 124 across the Paralana fault. Assuming a similar thinning for other formations implies east-side thicknesses 


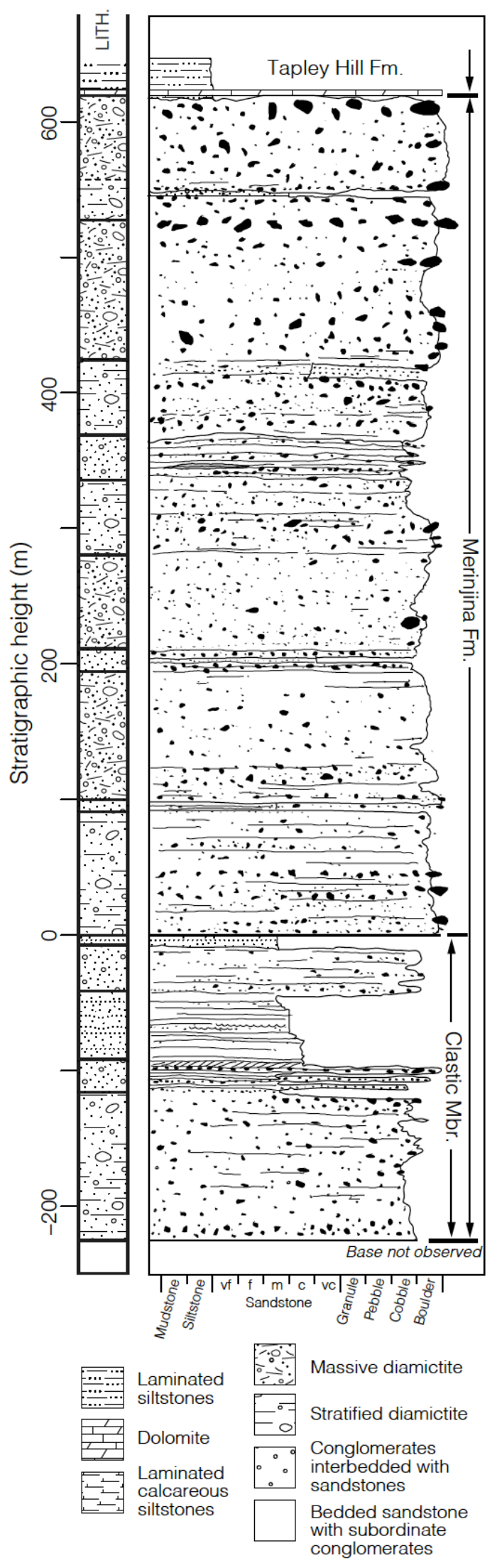

accordingly: Myrtle Springs Formation (0.7 km, west; $0.215 \mathrm{~km}$, east) and Skillogalee Dolomite (1.7 km, west; $0.52 \mathrm{~km}$, east). Collectively then, the thickness of Tonian sediments eroded at incision 'a' on Figure 2 east of Arkaroola is $\sim 1.1 \mathrm{~km}$.

Fig. 5 Summary stratigraphic log of Tillite Gorge, Arkaroola (Fig. 2). Glacial deposits overlie conglomerates.

\section{Magnetic susceptibility methods and results}

[8] Geologic constraints east of Arkaroola require that some, but not all, of the stratigraphically "deeper" Wooltana Volcanics were eroded (Fig. 2). To evaluate the intra-Wooltana Volcanics depth of erosion, we compare magnetic susceptibility values of basaltic clasts in the Tillite Gorge glacial deposits with nearby sections of Wooltana Volcanics. Magnetic susceptibility, the measure of magnetizable minerals in a rock, is widely used for mineral exploration due to both its affordable and expedient results and its ability to fingerprint "magnetic petrology" (Bleeker, 2012; Clark et al., 1992). The magnetic susceptibility of a protolith changes systematically over several orders of magnitude according to progressive metamorphism, hydrothermal alteration, 
149 and chemical weathering. Glacial erosion of exposed, chemically-weathered Wooltana basalt, could 150 therefore leave a systematic stratigraphic signature due to progressively deeper incision.

152 [9] Two reference sections of the Wooltana Volcanics (A and B; Figs. 2 and 6) were sampled on either 153 side of Tillite Gorge, and together constitute a composite Wooltana section. Section A is 154 stratigraphically lower and the base of section B is offset laterally along strike approximately where 155 Section A leaves off (Fig. 2). Magnetic susceptibility measurements were done on standard 156 palaeomagnetic specimens using a Bartington MS2 meter and averaged for each stratigraphic height $(\mathrm{n}=$ 1573 to 8 samples). Correlation of sections A and B into a composite Wooltana section is further supported 158 by matching magnetic susceptibilities of the top of $\mathrm{A}$ and the bottom of $\mathrm{B}$ (Fig. 6A and B). In both 159 Wooltana Volcanics sections, magnetic susceptibility values systematically decrease upsection, by 160 orders of magnitude in Section A (Fig. 6A) and along a steady linear reduction in Section B (Fig. 6B).

162 [10] In Tillite Gorge, hand sampling basalt clasts that have been river-polished would be difficult and 163 gas-powered drills are not allowed in the Arkaroola Wilderness Area. Consequently, susceptibility was 164 measured on flat, river-polished facets of mafic clasts using a standard-calibrated KT-10 hand-held, field 165 magnetic susceptibility meter. Flat surfaces optimize the precision of such handheld susceptibility 166 meters, making Tillite Gorge ideal (Fig. 3). Measurements were made on $\geq 20$ mafic clasts per site and 167 averaged, with obvious outliers excluded (i.e., one or more orders of magnitude from mean). Each site 168 sampled approximately $10 \mathrm{~m}$ in stratigraphic thickness or less. Magnetic susceptibility values were 169 normally distributed and varied little from clast-to-clast at any given stratigraphic level (Fig. 6C), 170 yielding comparable scatter to sites of Wooltana protolith (Fig. 6A and 6B). In the Tillite Gorge basaltic 171 clasts, magnetic susceptibility values increase significantly upsection (Fig. 6C). 


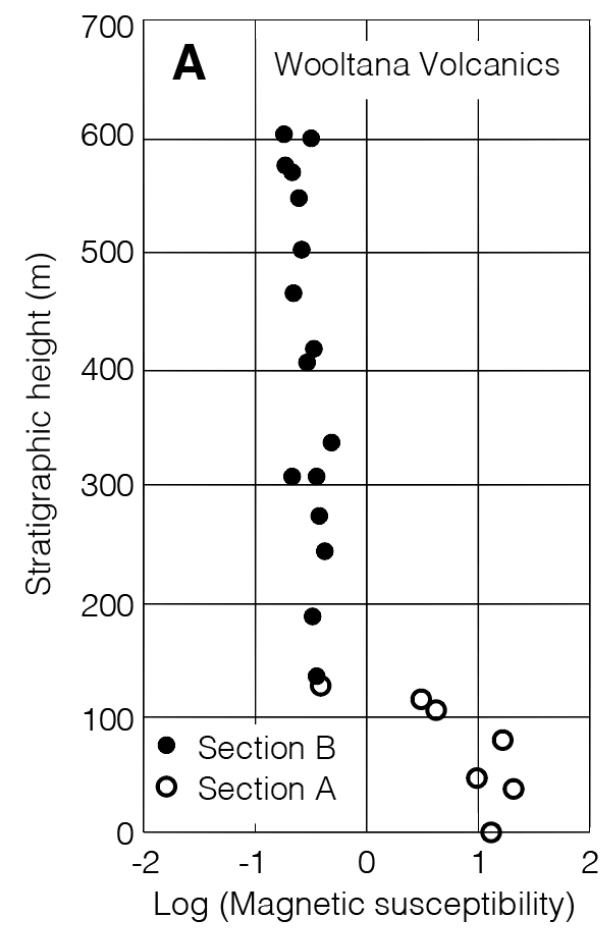

172

173

174

175

176

177

178

179

180

\section{Magnetic susceptibility interpretation}

182 [11] Due to an abundance of primary Fe-oxides including magnetite and titanomagnetite, magnetic

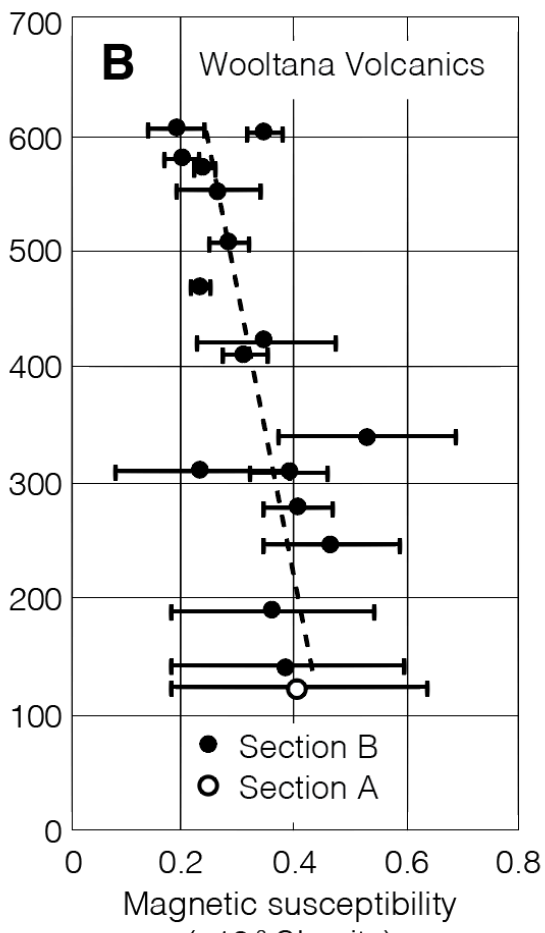

(x10-3 SI units)

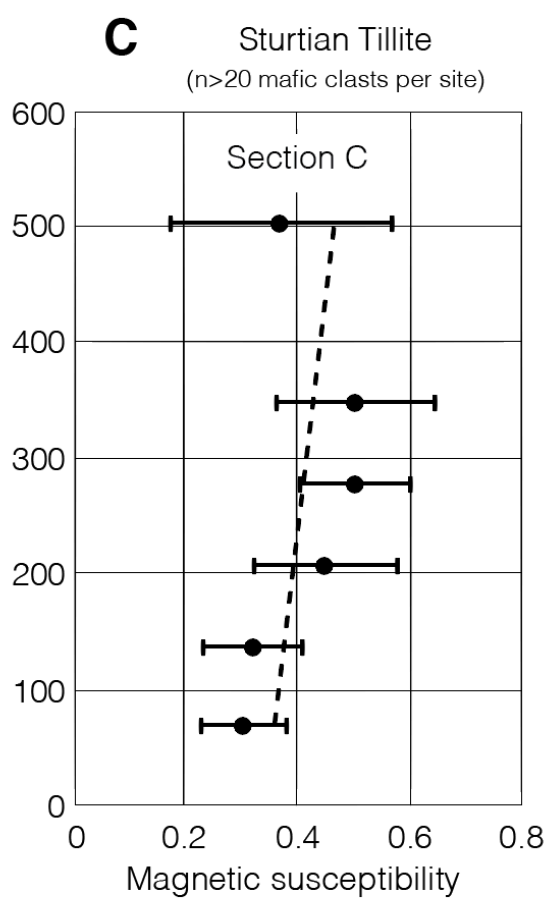

$\left(\times 10^{-3} \mathrm{SI}\right.$ units $)$
Fig. 6 Magnetic susceptibility of three measured stratigraphic sections east of Arkaroola (Fig. 2): (A and B) the Wooltana Volcanics and (C) the Merinjina Formation. Sections A and B constitute a composite section of the entire exposed Wooltana Volcanics, supported by magnetic susceptibility measurements. Section C represents 6 sites of mafic clasts measured through the Sturtian glaciation exposed in Tillite Gorge (Fig. 5). Mafic clasts in the Sturtian Merinjina Formation are derived from the nearby ca. $825 \mathrm{Ma}$ Wooltana Volcanics. Note different x-axis scale in (A) due to high susceptibility values of Wooltana Volcanics at section A. Error bars represent $2 \sigma$ values of site averages.

susceptibility is initially high $\left(\sim 10-100 \times 10^{-3}\right.$ SI units) in fresh, unmetamorphosed basalt and decreases

$\left(\sim 1 \times 10^{-3}\right.$ SI units) with low-grade metamorphism, chemical weathering, or hydrothermal alteration (Bleeker, 2012; Clark et al., 1992; Riveros et al., 2014). Magnetic susceptibility can therefore be used as a proxy to identify such processes. It is of course conceivable that the upsection decreases in magnetic susceptibility in the Wooltana Volcanics reference sections (Figs. 6A and 6B) could represent a primary 
magmatic trend, but we consider it more likely that the systematic reductions, slowly in upper section A and quickly in lower section B, simply indicates less chemical weathering with increasing depth.

191 [12] We would therefore consequently interpret the conversely increasing upsection trend in measured 192 magnetic susceptibility values in Tillite Gorge basaltic clasts as the Sturtian glaciation progressively 193 eroding deeper, less weathered levels of the Wooltana Volcanics. At the base of the Sturtian glacial 194 deposits in Arkaroola, low susceptibility values are akin to weathered basalts, but upward through the 195 glacial succession, magnetic susceptibility increases to values akin to unweathered lava (Fig. 6C). It is 196 not likely a coincidence that the Wooltana Volcanics is eroded only as deep as its low susceptibility 197 values (Fig. 6), suggesting that chemical weathering accompanied physical erosion.

[13] An alternative explanation is that the trend in magnetic susceptibility could relate to differential hydrothermal alteration through the volcanic sequences. Volcanic systems generally exhibit increased alteration intensity with depth (e.g., carbonatisation, sericitisation, chloritisation), owing to the availability of relatively high temperature (typically acidic) magmatic-hydrothermal fluids in the vicinity of the conduit (e.g., John et al., 2008) and subvolcanic magmatic plumbing system (e.g., Arnórsson et observed. Our observations are consistent with early erosion of fractured and weathered basalt flows, 207 followed by progressively 'fresher', i.e., deeper, lavas.

[14] Whether the upward increase in magnetic susceptibility is due to a trend in chemical weathering is 
211 were sampled in the Wooltana Volcanics, one can simply compare and correlate the clasts values with

212 those from the reference sections. The basaltic clasts (Fig. 6C) exhibit a "reverse stratigraphy" of the

213 Wooltana Volcanics (Fig. 6B), as one would expect from progressively deeper glacial erosion.

214 Furthermore, clast susceptibility values only match the Wooltana stratigraphy as deep as section 'B'

215 south of Tillite Gorge (Fig. 6B), but do not yield the significantly higher values of the stratigraphically

216 lower section 'A' north of Tillite Gorge (Fig. 6A). The intra-Wooltana erosive level as deduced from

217 magnetic susceptibility and geological constraints is internally consistent with an estimate of $\sim 500$

218 meters of erosion. Since the lowest diamictite strata include clasts of the Wooltana Volcanics, subglacial

219 weathering must have occurred long before the first glacial deposits were preserved. The upsection

220 increase in tillite magnetic susceptibility values can only be explained due to progressively deeper

221 erosion of the Wooltana Volcanics during glaciation. This constraint is unique for snowball diamictites

222 in that we know that the majority of the Merinjina Formation is synglacial. On the basis of our estimated

$223 \sim 500$-m-thick erosion of the Wooltana Volcanics (on top of the $\sim 1.1-\mathrm{km}$ erosion of overlying Tonian

224 sedimentary units; Fig. 2), we can further constrain the maximum depth of glacial erosion in the east

225 Arkaroola area to be $\sim 1.6 \mathrm{~km}$.

226

\section{Discussion}

228 [15] Given a 58-Myr-long Sturtian glaciation (Cox et al., 2018; Rooney et al., 2015), how much glacial 229 erosion might we expect? Depending predominantly on latitude and altitude, glacial erosion rates for the 230 Quaternary ice ages vary across several orders of magnitude (Delmas et al., 2009; Hallet et al., 1996). A 231 minimum estimate of glacial erosion for the Sturtian glaciation based on very low erosion rates $(\sim 10 \mathrm{~m}$ $232 \mathrm{Myr}^{-1}$ ) representative of polar glaciers and thin temperate plateau glaciers (Hallet et al., 1996) would 233 result in only $\sim 600 \mathrm{~m}$ of glacial erosion. Such relatively limited erosion is characteristic of the glacial 
234 trough west of Arkaroola (Figs. 2 and 7). If faster rates of Quaternary glacial erosion are applied, as can 235 occur in localized glacial trough incisions, significantly greater depths are expected, on the scale of 236 kilometers. Such deep incision is characteristic of the glacial trough east of Arkaroola (Figs. 2 and 7).
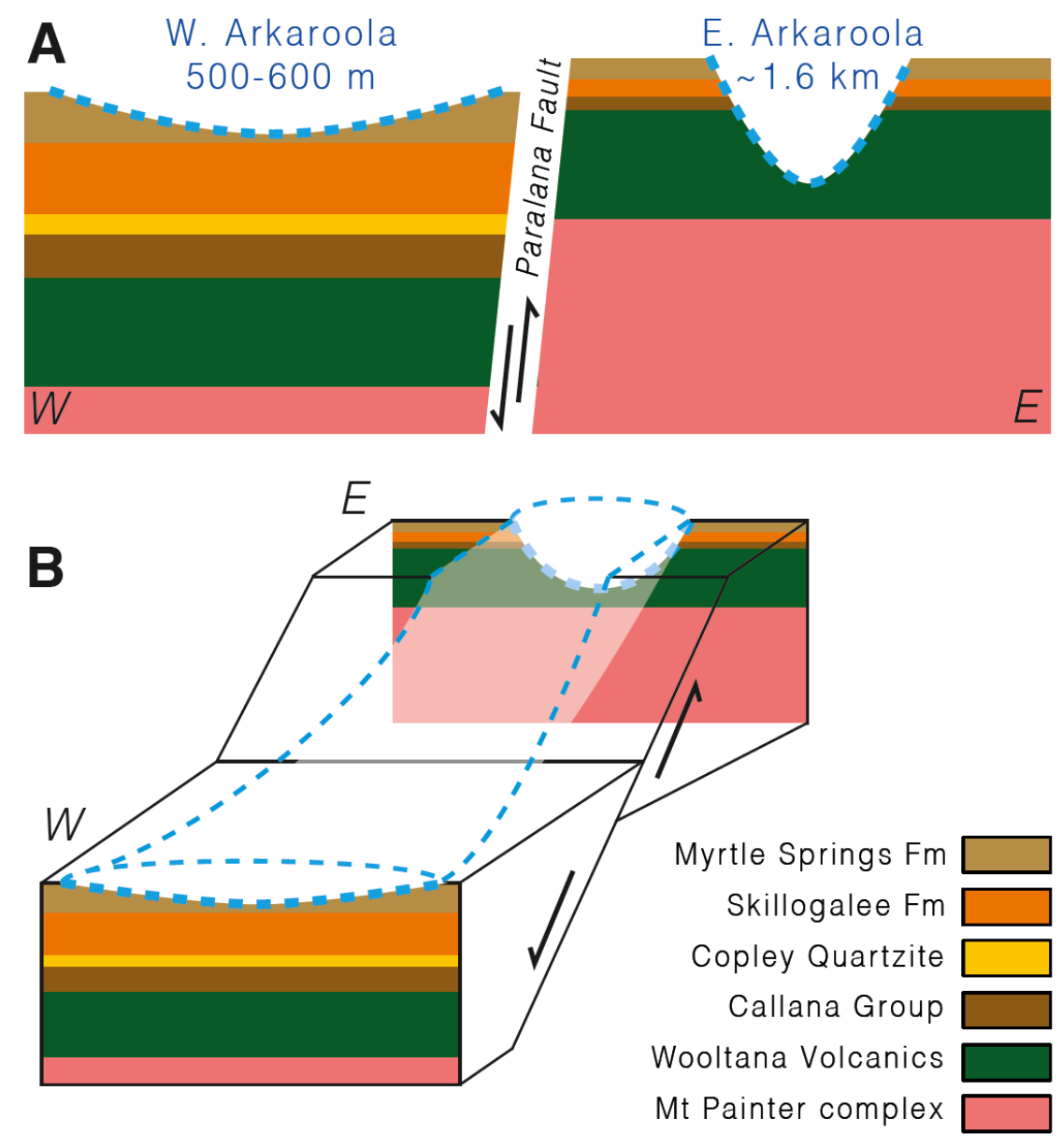

238 Fig. 7 (A) Schematic cross section of glacial troughs on either side of the Paralana Fault, illustrating how incision 239 appears to be significantly increased by tectonic uplift. Sedimentary thicknesses (except that of the thin Copley 240 Quartzite) and glacial incisions are shown to scale. Fault offset unknown. Although depicted in (A) as apparently 241 two glacial troughs, the two incisions documented here actually represent the same glacial trough (Fig. 2) with 242 variable depths of incision, as depicted in the block diagram (B). According to the interpretation of a single 243 trough, equal ice mass flux at both incisions is depicted by their equal cross-sectional areas.

245 [16] Less evidence for glacial incision during snowball Earth has been documented than one may expect 246 for such protracted glacial epochs (Hoffman et al., 2017). Whether the apparent lack of evidence of 
247 incision is an artifact due to insufficient study on the topic or reflects the hypothesized weakened 248 snowball hydrologic cycle (Partin and Sadler, 2016) is unclear. Table 1 summarizes the documented 249 cases of Cryogenian glacial troughs. Interestingly, $70 \%$ of documented glacial incisions are Sturtian 250 (30\% are Marinoan) and all examples of deep erosion are Sturtian. Future work must test whether this 251 apparent disparity is significant or not. The most obvious explanation for greater incision during the 252 Sturtian than the Marinoan is its longer duration (Partin and Sadler, 2016). The stark contrast in depth of 253 incision between the two glaciations could also reflect the long-term effects on paleotopography of the 254 rift-to-drift transition of the vanishing Rodinia supercontinent.

Table 1. Evidence and depths of Cryogenian glacial incision

\begin{tabular}{|l|c|c|l|}
\hline Locality & Glaciation & Depth $\mathbf{( m )}$ & References \\
\hline Namibia, Duurwater trough & Marinoan & 100 & (Hoffman, 2005) \\
\hline Central Australia, Ellery Creek & Sturtian & 120 & (Lindsay, 1989) \\
\hline South Australia & Marinoan & 150 & (Dyson and von der Borch, 1994) \\
\hline South Australia & Marinoan & 200 & (Rose et al., 2013) \\
\hline Oman & Sturtian & 210 & (Kellerhals and Matter, 2003; Rieu et al., 2006) \\
\hline Utah, USA & Sturtian & 425 & (Christie-Blick, 1997) \\
\hline Namibia & Sturtian & 450 & (Hoffman et al., 2017) \\
\hline South Australia, W. Arkaroola & Sturtian & $500-600$ & This study \\
\hline Utah, USA & Sturtian & 900 & (Christie-Blick, 1997) \\
\hline South Australia, E. Arkaroola & Sturtian & 1600 & This study \\
\hline
\end{tabular}

257 [17] Our estimate of maximum glacial incision east of Arkaroola represents the deepest glacial trough 258 documented for snowball Earth (Table 1). We must emphasize that this degree of incision ( 1.6 km) was 259 heavily localized to define a deeply incised valley and does not integrate to basin-scale erosion. Several 260 factors can affect glacial erosion including: (i) temperature, (ii) precipitation, (iii) frictional heating 261 (cold- vs. wet-based glaciers), (iv) ice velocity and bedrock character (soft vs. hard), and (iv) tectonic 262 uplift. Comparison between the depth of incision of glacial valleys on either side of the Paralana Fault 
263 bisecting the Arkaroola area suggests strongly that the deep glacial trough of the east side incises a 264 tectonically uplifted horst (Fig. 7). Mawson (1949) first noted the difference of erosion across the

265 Paralana Fault. Indeed, greater thicknesses of equivalent formations west of the Paralana Fault have 266 been interpreted as a graben (Paul et al., 1999), where glacial erosion is significantly less (Fig. 7). The 267 deepest glacial troughs of West Greenland of similar $>1 \mathrm{~km}$ depth are similarly attributed to uplift268 enhanced incision (Bonow et al., 2006). It is tempting to argue that the deep, tectonically uplifted glacial 269 trough documented east of Arkaroola is exceptional. Although it would be incorrect to globally integrate 270 such a $\sim 1.6-\mathrm{km}$-deep incision since it only occurs locally, it is also possible that such glacial troughs 271 were not uncommon for snowball Earth. The nearby, exceptionally thick Sturtian diamictite $(>3,000 \mathrm{~m})$ 272 of the Yudnamutana trough is a fault-controlled basin and supports the idea of synsedimentary and 273 synglacial extensional tectonics (Young and Gostin, 1989). Like the eastern Arkaroola ice stream 274 documented here, the Yudnamutana trough overlies multiple underlying units (Burra Group, Callana 275 Group, and crystalline basement), implying significant glacial incision, consistent with its exceptional 276 thickness.

278 [18] Cryogenian glaciations occurred during the rifting of supercontinent Rodinia (Gernon et al., 2016; 279 Hoffman and Li, 2009; Kirschvink, 1992) and tectonic rifting is commonly invoked to explain the 280 accommodation of Cryogenian glacial rainout (Eisbacher, 1985; Eyles and Januszczak, 2004; Prave, 281 1999), particularly for thick diamictites (McMechan, 2000; Young and Gostin, 1989). Substantial 282 topography created by uplifted rifted margins (Garfunkel, 1988) should have facilitated relatively 283 efficient glacial incision. Thermochronology indicates $\sim 6-\mathrm{km}$ of exhumation on the North American 284 continent between 850-680 Ma, corresponding to the breakup of Rodinia and potentially due, at least in 285 part, to Cryogenian glaciation (DeLucia et al., 2018). Active tectonics of the time, combined with the 
thick pre-Sturtian regolith (Swanson-Hysell et al., 2012), may have allowed for deep glacial troughs to develop despite the cold, dry snowball climate (Partin and Sadler, 2016).

\section{Conclusion}

[19] Estimating the degree of glacial erosion during snowball Earth is a relatively recent topic of study 291 (Partin and Sadler, 2016). The Sturtian snowball Earth, the first and longer of the two Cryogenian 292 events, is one of the longest-known glaciations in Earth history and therefore had the potential to have 293 promoted deep physical weathering over the protracted interval. We present evidence for increasing 294 magnetic susceptibility values of mafic clasts for a portion of the Sturtian glaciation that we interpret as 295 progressively deeper erosion of nearby volcanic complexes. Assuming conservative erosion rates 296 associated with Quaternary ice ages, the $\sim 58$-Myr-long Sturtian glaciation may have removed $\sim 600 \mathrm{~m}$. 297 Our field observations indicate such an estimate is a minimum in the field area. Where active tectonic 298 uplift related to Rodinia rifting appears to have accelerated glacial incision in our field area, a deep $\sim 1.6$ $299 \mathrm{~km}$ incision is also inferred. The highly spatially variable rates of glacial incision observed in the northern Flinders Ranges of South Australia are consistent with Cryogenian glacial incisions documented elsewhere in the world, and may be the hallmark of active tectonics and horst-and-graben topography associated with the breakup of supercontinent Rodinia.

\section{REFERENCES}

Arnorsson, S., Stefansson, A., and Orn Bjarnason, J., 2007, Fluid-fluid interactions in geothermal systems: Reviews in Mineralogy and Geochemistry, v. 65, p. 259-312.

Bao, X., Zhang, S., Jiang, G., Wu, H., Li, H., Wang, X., An, Z., and Yang, T., 2018, Cyclostratigraphic constraints on the duration of the Datangpo Formation and the onset age of the Nantuo (Marinoan) glaciation in South China: Earth and Planatary Science Letters, v. 483, p. 52-63.

Bleeker, W., 2012, The use of hand-held magnetic susceptibility meters in the field: an invaluable tool in regional studies of dyke swarms: Geological Survey of Canada, v. Open File 7139, 2012, p. 1 sheet. 
Bonow, J. M., Lidmar-Bergstrom, K., and Japsen, P., 2006, Palaeosurfaces in central West Greenland as reference for identification of tectonic movements and estimation of erosion: Global And Planetary Change, v. 50, p. 161-183.

Budyko, M. I., 1969, The effect of solar radiation variations on the climate of the Earth: Tellus, v. 21, p. 611-619.

Christie-Blick, N., 1997, Neoproterozoic sedimentation and tectonics in west-central Utah: Bringham Young University Geology Studies, v. 42, p. 1-30.

Clark, D. A., French, D. H., Lackie, M. A., and Schmidt, P. W., 1992, Magnetic petrology: Application of integrated rock magnetic and petrological techniques to geological interpretation of magnetic surveys: Exploration Geophysics, v. 23, p. 65-68.

Coats, R. P., 1973, COPLEY map sheet and explanatory notes, Geological Atlas of South Australia 1:250,000 series: Geological Survey of South Australia, Australia.

Cox, G. M., Isakson, V., Hoffman, P. F., Gernon, T. M., Schmitz, M. D., Shahin, S., Collins, A. S., Preiss, W. V., Blades, M. L., Mitchell, R. N., and Nordsvan, A., 2018, U-Pb zircon (CA-IDTIMS) age supports globally synchrounous Sturtian deglaciation: Precambrian Research, v. Accepted.

Daily, B., Gostin, V. A., and Nelson, C. A., 1973, Tectonic origin for an assumed glacial pavement of late Proterozoic age, South Australia: Journal of the Geological Society of Australia, v. 20, p. 75 78.

Delmas, M., Calvet, M., and Gunnell, Y., 2009, Variability of Quaternary glacial erosion rates - A global perspective with special reference to the Eastern Pyrenees: Quaternary Science Reviews, v. 28, p. 484-498.

DeLucia, M. S., Guenthner, W. R., Marshak, S., Thomson, S. N., and Ault, A. K., 2018, Thermochronology links denudation of the Great Unconformity surface to the supercontinent cycle and snowball Earth: Geology, v. 46, p. 167-170.

Dyson, I. A., and von der Borch, C. C., 1994, Sequence stratigraphy of an incised-valley fill: The Neoproterozoic Seacliff Sandstone, Adelaide Geosyncline, South Australia, in Dalrymple, R. W., Boyd, R., and Zaitlin, B. A., eds., Incised-Valley Systems: Origin and Sedimentary Sequences, SEPM (Society for Sedimentary Geology) Special Publication 51, p. 209-222.

Eisbacher, G. H., 1985, Late Proterozoic rifting, glacial sedimentation, and sedimentary cycles in the light of Windermere deposition, western Canada: Palaeogeography, Palaeoclimatology, Palaeoecology, v. 51, p. 231-254.

Evans, D. A. D., 2000, Stratigraphic, geochronological, and paleomagnetic constraints upon the Neoproterozoic climate paradox: American Journal of Science, v. 300, p. 347-433.

-, 2003, A fundamental Precambrian-Phanerozoic shift in earth's glacial style?: Tectonophysics, v. 375, p. 353-385.

Evans, D. A. D., Beukes, N. J., and Kirschvink, J. L., 1997, Low-latitude glaciation in the Palaeoproterozoic era: Nature, v. 386, p. 262-266.

Eyles, N., and Januszczak, N., 2004, 'Zipper-rift': A tectonic model for Neoproterozoic glaciations during the breakup of Rodinia after 750 Ma: Earth Science Reviews, v. 65, p. 1-73.

Garfunkel, Z., 1988, Relation between continental rifting and uplifting: evidence from the Suez rift and northern Red Sea: Tectonophysics, v. 150, p. 33-49.

Gernon, T. M., Hincks, T. K., Tyrell, T., Rohling, E. J., and Palmer, M. R., 2016, Snowball Earth ocean chemistry driven by extensive ridge volcanism during Rodinia breakup: Nature Geoscience, v. 9, p. 242-248. 
Hallet, B., Hunter, L., and Bogen, J., 1996, Rates of erosion and sediment evacuation by glaciers: A review of field data and their implications: Global And Planetary Change, v. 12, p. 213-235.

Hoffman, P. F., 2005, 28th DeBeers Alex Du Toit Memorial Lecture: On Cryogenian (Neoproterozoic) ice-sheet dynamics and the limitations of the glacial sedimentary record: South African Journal of Geology, v. 108, p. 557-577.

Hoffman, P. F., Kaufman, A. J., Halverson, G. P., and Schrag, D. P., 1998, A Neoproterozoic snowball Earth: Science, v. 281, p. 1342-1346.

Hoffman, P. F., Lamothe, K. G., LoBianco, S. J. C., Hodgskiss, M. S. W., Bellefroid, E. J., Johnson, B. W., Hodgin, E. B., and Halverson, G. P., 2017, Sedimentary depocenters on Snowball Earth: Case studies from the Sturtian Chuos Formation in northern Namibia: Geosphere, v. 13, p. 811837.

Hoffman, P. F., and Li, Z.-X., 2009, A palaeogeographic context for Neoproterozoic glaciation: Palaeogeography, Palaeoclimatology, Palaeoecology, v. 277, p. 158-172.

Huang, Q., Kamenetsky, V. S., McPhie, J., Ehrig, K., Meffre, S., Maas, R., Thompson, J., Kamenetsky, M., Chambefort, I., Apukhtina, O., and Hu, Y., 2015, Neoproterozoic (ca. 820-830 Ma) mafic dykes at Olympic Dam, South Australia: Links with the Gairdner Large Igneous Province: Precambrian Research, v. 271, p. 160-172.

John, D. A., Sisson, T. W., Breit, G. N., Rye, R. O., and Vallance, J. W., 2008, Characteristics, extent and origin of hydrothermal alteration at Mount Rainier Volcano, Cascades Arc, USA: Implications for debris-flow hazards and mineral deposits: Journal Of Volcanology And Geothermal Research, v. 175, p. 289-314.

Keller, C. B., Husson, J. M., Mitchell, R. N., Bottke, W. F., Gernon, T. M., Boehnke, P., Bell, E. A., Swanson-Hysell, N. L., and Peters, S. E., 2019, Neoproterozoic glacial origin of the Great Unconformity: Proceedings of the National Academy of Sciences, v. 116, p. 1136-1145.

Kellerhals, P., and Matter, A., 2003, Facies analysis of a glaciomarine sequence, the Neoproterozoic Mirbat Sandstone Formation, Sultanate of Oman: Eclogae Geologicae Helvetiae, v. 96, p. 49-70.

Kirschvink, J. L., 1992, Late Proterozoic Low-Latitude Global Glaciation: the Snowball Earth, in Schopf, J. W., and Klein, C., eds., The Proterozoic Biosphere: A Multidisciplinary Study: Cambridge, United Kingdom, Cambridge Univeristy Press, p. 51-52.

Le Heron, D. P., Busfield, M. E., and Collins, A. S., 2014, Bolla Bollana boulder beds: A Neoproterozoic trough mouth fan in South Australia?: Sedimentology, v. 61, p. 978-995.

Lindsay, J. F., 1989, Depositional controls on glacial facies associations in a basinal setting, Late Proterozoic, Amadeus Basin, central Australia: Palaeogeography, Palaeoclimatology, Palaeoecology, v. 73, p. 205-232.

Liu, Y.-G., and Peltier, W. R., 2013, Sea level variations during snowball Earth formation: 1. A preliminary analysis: Journal of Geophysical Research: Solid Earth, v. 118, p. 4410-4424.

Macdonald, F. A., Schmitz, M. D., Crowley, J. L., Roots, C. F., Jones, D. S., Maloof, A. C., Strauss, J. V., Cohen, P. A., Johnston, D. T., and Schrag, D. P., 2010, Calibrating the Cryogenian: Science, v. 327, p. 1241-1243.

Mawson, D., 1949, Sturtian tillite of Mount Jacob and Mount Warren Hastings, north Flinders Ranges: Transactions of the Royal Society of South Australia, v. 72, p. 244-251.

McMechan, M. E., 2000, Vreeland Diamictites - Neoproterozoic glaciogenic slope deposits, Rocky Mountains, northeast Britsih Columbia: Bulletin of Canadian Petroleum Geology, v. 48, p. 246261.

Mirams, R. C., 1964, A Sturtian glacial pavement at Merinjina Well, near Wooltana: Quarterly Geological Notes of the Geological Survey of South Australia, v. 11, p. 4-6. 
Partin, C. A., and Sadler, P. M., 2016, Slow net sediment accumulation sets snowball Earth apart from all younger glacial episodes: Geology, v. 44, p. 1019-1022.

Paul, E., Flottmann, T., and Sandiford, M., 1999, Structural geometry and controls on basementinvolved deformation in the northern Flinders Ranges, Adelaide Fold Belt, South Australia: Australian Journal of Earth Sciences, v. 46, p. 343-354.

Prave, A. R., 1999, Two diamictites, two cap carbonates, two $2{ }^{13} \mathrm{C}$ excursions, two rifts: The Neoproterozoic Kingston Peak Formation, Death Valley, California: Geology, v. 27, p. 339-342.

Preiss, W. V., 1987, The Adelaide Geosyncline--late Proterozoic stratigraphy, sedimentation, palaeontology and tectonics: Geological Survey South Australia Bulletin, v. 53, p. 438.

Rieu, R., Allen, P. A., Etienne, J. L., Cozzi, A., and Wiechert, U., 2006, A Neoproterozoic glacially influenced basin margin succession and 'atypical' cap carbonate associated with bedrock paleovalleys, Mirbat area, southern Oman: Basin Research, v. 18, p. 471-496.

Riveros, K., Veloso, E. A. E., Campos, E., Menzies, A., and Veliz, W., 2014, Magnetic properties related to hydrothermal alteration processes at the Escondida porphyry copper deposit, northern Chile: Miner Deposita, v. 49, p. 693-707.

Rooney, A. D., Strauss, J. V., Brandon, A. D., and Macdonald, F. A., 2015, A Cryogenian chronology: Two long-lasting synchronous Neoproterozoic glaciations: Geology, v. 43, p. 459-462.

Rose, C. V., Maloof, A. C., Schoene, B., Ewing, R. C., Linnemann, U., Hofmann, M., and Cottle, J. M., 2013, The end-Cryogenian glaciation of South Australia: Geoscience Canada, v. 40, p. 256-293.

Sellers, W. D., 1969, A global climatic model based on the energy balance of the Earth-atmosphere system: Journal of Applied Meteorology, v. 8, p. 392-400.

Shields-Zhou, G. A., Porter, S. M., and Halverson, G. P., 2016, A new rock-based definition for the Cryogenian Period (circa 720-635 Ma): Episodes, v. 39, p. 3-8.

Swanson-Hysell, N. L., Maloof, A. C., Kirschvink, J. L., Evans, D. A. D., Halverson, G. P., and Hurtgen, M. T., 2012, Constraints on Neoproterozoic paleogeography and Paleozoic orogensis from paleomagnetic records of the Bitter Springs Formation, Amadeus Basin, central Australia: American Journal of Science, v. 312, p. 817-884.

Wingate, M. T. D., Campbell, I. H., Compston, W., and Gibson, G. M., 1998, Ion microprobe U-Pb ages for Neoproterozoic basaltic magmatism in south-central Australia and implications for the breakup of Rodinia: Precambrian Research, v. 87, no. 3-4, p. 135-159.

Young, G. M., and Gostin, V. A., 1989, An exceptionally thick upper Proterozoic (Sturtian) glacial sucession in the Mount Painter area, South Australia: Geological Society of America Bulletin, v. 101, p. 834-845.

Zhao, J., McCulloch, M. T., and Korsch, R. J., 1994, Characterization of a plume-related $\sim 800 \mathrm{Ma}$ magmatic event and its implications for basin formation in central-southern Australia: Earth and Planetary Science Letters, v. 121, p. 349-367. 